\title{
Sustainable drainage system site assessment method using urban ecosystem services
}

\author{
Chunglim Mak ${ }^{1} \cdot$ Miklas Scholz $^{2,3} \cdot$ Philip James $^{1}$ \\ Published online: 6 September 2016 \\ (C) The Author(s) 2016. This article is published with open access at Springerlink.com
}

\begin{abstract}
The United Kingdom's recently updated approach to sustainable drainage enhanced biodiversity and amenity objectives by incorporating the ecosystem approach and the ecosystem services concept. However, cost-effective and reliable methods to appraise the biodiversity and amenity values of potential sustainable drainage system (SuDS) sites and their surrounding areas are still lacking, as is a method to enable designers to distinguish and link the amenity and biodiversity benefits that SuDS schemes can offer. In this paper, therefore, the authors propose two ecosystem services- and disservicesbased methods (i.e. vegetation structure cover-abundance examination and cultural ecosystem services and disservices variables appraisal) to aid SuDS designers to distinguish and link amenity and biodiversity benefits, and allow initial site assessments to be performed in a cost-effective and reliable fashion. Forty-nine representative sites within Greater Manchester were selected to test the two methods. Amenity and biodiversity were successfully assessed and habitat for species, carbon sequestration, recreation and education ecosystem services
\end{abstract}

Electronic supplementary material The online version of this article (doi:10.1007/s11252-016-0593-6) contains supplementary material, which is available to authorized users.

Miklas Scholz

miklas.scholz@tvrl.lth.se; m.scholz@salford.ac.uk

1 School of Environment and Life Science, Peel Building, The University of Salford, Greater Manchester M5, 4WT, Salford, England, UK

2 Division of Water Resources Engineering, Faculty of Engineering, Lund University, P.O. Box 118, 22100 Lund, Sweden

3 School of Computing, Science and Engineering, The University of Salford, Newton Building, Salford Greater Manchester M5 4WT, Salford, England, UK scores were produced, which will support SuDS retrofit design decision-making. Large vegetated SuDS sites with permanent aquatic features were found to be most capable of enhancing biodiversity- and amenity-related ecosystem services. Habitat for species and recreation ecosystem services were also found to be positively linked to each other. Finally, waste bins on site were found to help reduce dog faeces and litter coverage. Overall, the findings presented here enable future $\mathrm{SuDS}$ retrofit designs to be more wildlife friendly and socially inclusive.

Keywords Best management practice $\cdot$ Biodiversity $\cdot$ Carbon sequestration $\cdot$ Culture $\cdot$ Habitat for species $\cdot$ Vegetation structure

\section{Introduction}

The SuDS approach is deemed to be an important tool to enable the UK and other signatory countries to achieve the Water Framework Directive's good surface water status by 2021 for interim targets or 2027 for full compliance (Environment Agency 2014). Sustainable drainage is an approach that facilitates surface waterbodies to achieve the Water Framework Directive's good surface water status by offering various storm water management and treatment services via a set of storm water best management practise techniques (e.g., rainwater harvesting, pervious pavements, filter strips, swales, green roofs, ponds, infiltration devices, wetlands, below-ground storage and bio-retention) according to Scholz (2015). These techniques can facilitate four ecosystem protection activities (1) to combat the changing rainfall patterns caused by climate change by promoting a more natural way of draining surface runoff (Carter et al. 2015); (2) to compensate the loss of permeable land due to increased 
urbanisation by providing extra capacity to temporary store storm water runoff and release the water gradually in a controlled manner (Woods-Ballard et al. 2007; Dickie et al. 2010; Moore and Hunt 2012; Scholz et al. 2013); (3) to tackle the three urban runoff activities (road run-off, discharge from surface water drains and foul waste pipes being wrongly connected with surface water drains) that contribute to urban diffuse pollution by utilising the treatment train concept (prevention as well as source, site and regional control (WoodsBallard et al. 2015)); and (4) to promote the increasing popular vegetated SuDS techniques, which contribute to reversing habitat fragmentation by acting as wildlife corridors and buffer zones to connect and protect separated and isolated habitats due to urbanisation (Kim 2004; Brenneisen 2006; Oberndorfer et al. 2007; Jackson and Boutle 2008; Viol et al. 2009; Tonietto et al. 2011; Ksiazek et al. 2012; Moore and Hunt 2012; Bates et al. 2013; Briers 2014).

The SuDS approach, therefore, can be used to combat increased flood risk, amplified diffuse pollution and enhanced habitat fragmentation caused by increased urbanisation and climate change, which is causing capacity stress and overtaxing of existing urban drainage infrastructure (Millennium Ecosystem Assessment 2005; Intergovernmental Panel on Climate Change 2007; Pitt 2007; Woods-Ballard et al. 2007; Semadeni-Davies et al. 2008; Astaraie-Imani et al. 2012; Department of Environment, Food and Rural Affairs 2012; UK National Ecosystem Assessment 2011, 2014).

There are many similar storm water management approaches elsewhere in the world. The low impact development (LID) and the water sensitive urban design (WSUD) concepts are the most prominent in the English-speaking world (Fletcher et al. 2014). All these approaches, however, place the most emphasis on managing the quantity and controlling the quality of storm water, whereas biodiversity improvements and amenity provisions are of secondary considerations (Woods-Ballard et al. 2007; Fletcher et al. 2014). This leads to sustainable storm water management design and planning practises being site-specific and engineering-focused (Jackson and Boutle 2008; Ashton et al. 2010; Wise et al. 2010; Natural England 2011; Moore and Hunt 2012; Ellis 2013; Graham et al. 2013; Scholz et al. 2013; Scholz and Uzomah 2013; Uzomah et al. 2014; Woods-Ballard et al. 2015).

In order to address the biodiversity and amenity short-comings, the Construction Industry Research and Information Association (CIRIA) recently released the updated version of their SuDS Manual (Woods-Ballard et al. 2015). This manual helps to overcome many previous concerns by incorporating the ecosystem approach and using the ecosystem services concept for the design and planning of SuDS schemes (Woods-Ballard et al. 2015).

The ecosystem approach recognises the fact that humans are part of the ecosystem, and their activities are subject to the natural limits and function of the ecosystems (Maltby 2010). The approach has twelve principles, and they collectively aim to incorporate the economy, society and environment within three integrated objectives: (1) to fairly and equally share the benefits generated by nature; (2) to sustainably use resources generated by nature; and (3) to conserve nature for the benefits of future generations (Secretariat of the Convention on Biological Diversity 2004).

The ecosystem services are defined as the benefits generated by nature that are beneficial to human well-being; physically, mentally and socially (Daily et al. 1997; Costanza et al. 1998; de Groot et al. 2002; Millennium Ecosystem Assessment 2005; Boyd and Banzhaf 2007; Wallace 2007; Fisher et al. 2009; The Economics of Ecosystems and Biodiversity 2010; UK National Ecosystem Assessment 2011; Haines-Young et al. 2012; Hanson et al. 2012; Bastian et al. 2013; Scholz and Uzomah 2013). The ecosystem services concept stems from the ecosystem approach, and is justified to be one of the many tools in the management of nature to protect the structures and functions of various ecosystems (Secretariat of the Convention on Biological Diversity 2004). With the new SuDS approach actively recommending the integration of (predominately vegetated) SuDS techniques with other green infrastructures such as parks, nature reserves and gardens (Woods-Ballard et al. 2015), storm water management design, therefore, can now be undertaken both sustainably and also make active improvements to the ecosystem of the entire catchment area, whilst offering social benefits to people living within the catchment (WoodsBallard et al. 2015). This improvement to the SuDS approach is a substantial improvement compared to both the LID and the WSUD approaches.

However, the new SuDS approach lacks cost-effective, rapid, simple and reliable methods to appraise the biodiversity and amenity values of potential SuDS sites and their surrounding areas. This work is a requirement for the initial site and development characteristics surveys to support the planning and design of SuDS systems in accordance with the updated SuDS manual (Woods-Ballard et al. 2015). The new SuDS approach also lacks ways to appraise ecosystem disservices, which are end-products generated by the natural environment that have negative effects, or costs, to human beings (Lyytimaki et al. 2008; Lyytimaki and Sipila 2009; Dunn 2010; Limburg et al. 2010; Escobedo et al. 2011; GómezBaggethun and Barton 2013; Shapiro and Báldi 2014; von Döhren and Haase 2015). In order to treat storm water at or near their sources, SuDS developments are often located within urban environments (i.e. near people's homes and places of work), which are designed to be suitable for human lifestyles. However, with the continued expansion of towns and cities, wildlife species are forced to find new niches and alternative ways to survive within areas where people live and work (Lyytimaki and Sipila 2009; Garroway and Sheldon 2013). 
Therefore, the interaction of humans and wild animals in urban areas, facilitated further by SuDS sites (vegetated and retain water), can potentially be detrimental to the life of humans (Garroway and Sheldon 2013). Issues such as interactions between humans and (parasite- or disease-infected) wild animals (Polley 2005), and the sense of fear and unrest associated with natural environments (Jones et al. 2006; Lyytimaki et al. 2008; Sustainable Cities Institute 2012) cannot be ignored and have to be assessed properly.

Therefore, this paper proposes two generic methods (one for assessing biodiversity and one for appraising amenity) based on the ecosystem services and disservices concepts to enable the initial site and development characteristics surveys to be performed in a cost effective and reliable fashion. The two methods are: (1) vegetation structure cover-abundance examination; and (2) cultural ecosystem services and disservices variables appraisal. The analysis of four example ecosystem services (habitat for species, carbon sequestration, recreation and education) will be discussed in this paper. These ecosystem services were chosen because they best reflect upon the biodiversity and amenity potential of the new SuDS approach. Additionally the analysis of three example ecosystem disservices variables (dog faeces, litter and bins) will also be discussed in this paper.

The scope of this paper is to present new inter-linked generic methodologies for SuDS site assessment using urban ecosystem services, and not to review and discuss ecosystem services and disservices for a large variety of case study sites. Furthermore, any specific references to case study sites are purely for illustration purposes.

\section{Case study and methodology}

\section{Overview}

The plan is to describe a new methodology and then to test it using sites in Greater Manchester (situated in the North West of England), which was chosen as the case study area for which 49 sites were randomly selected for the research. Table A1 within the online supplementary material section contains the list of 49 sites, along with their geographical locations, chosen for the verification of the vegetation structure cover-abundance examination and the cultural ecosystem services and disservices variables appraisal.

The development of the vegetation structure coverabundance examination has several stages: (1) five modifications were made to the Tzoulas-James method (Tzoulas and James 2009) to develop the vegetation structure coverabundance data collection method for this research; (2) steps to measure vegetation structure cover-abundance data were illustrated; and (3) scoring procedures were illustrated to combine the data together to produced habitat for species and carbon sequestration scores. These stages combined form the examination method and are explained in the following sections. Additionally, the creation of the cultural ecosystem services and disservices variables appraisal method and steps to survey the variables are also explained in the following sub-sections.

\section{Development of the vegetation structure cover-abundance data collection method}

The vegetation structure cover-abundance data collection was adapted and modified from the Tzoulas-James method (Tzoulas and James 2009). Tzoulas and James (2009) developed their method to provide a way to analyse the biodiversity potential and subsequent ecosystem services of urban green spaces. This method was chosen ahead of other rapid, nonexpert, ecosystem services site assessment methods (O'Farrell et al. 2012; Peh et al. 2013; Scholz and Uzomah 2013; Uzomah et al. 2014; Beumer and Martens 2015), because it allowed for ecologically justifiable biodiversity assessments to be carried out and was proven to work effectively when used by non-specialists (Tzoulas and James 2009; Iswoyo et al. 2013; Voigt and Wurster 2015). However, in order to examine the ecosystem services of vegetated SuDS sites, several modifications to the Tzoulas-James method were made. Table 1 details the modified Tzoulas-James method for this research.

The first modification made was to substitute the Domin Scale with the Braun-Blanquet scale (Sutherland 2006), which has five percentage classes $(0 \%$ : Braun-Blanquet value $=0$; $<1 \%$ : Braun-Blanquet value $=1 ; 1$ to $5 \%$ : Braun-Blanquet value $=2 ; 6$ to $25 \%$ : Braun-Blanquet value $=3 ; 26$ to $50 \%$ : Braun-Blanquet value $=4 ; 51$ to $75 \%$ : Braun-Blanquet value $=5 ; 76$ to $100 \%$ : Braun-Blanquet value $=6$ ). The reasons for adopting the Braun-Blanquet scale for this research instead of using the Domin scale are as follows: (a) No vegetation species data collection is required, which simplified and speededup the survey process so that non-experts with no botanical training can also use the method; (b) Since the scale is biased towards rarity, it allows analysis of well-defined habitat types that do not dominate a particular site but provide habitats for various species and other ecosystem services to humans; (c) The Braun-Blanquet scale is suitable for ordinal data analysis (Podani 2006), which is similar to the ecosystem services results presented in the UK National Ecosystem Assessment (UK National Ecosystem Assessment 2011, 2014), hence ensuring compatibility with existing ecosystem services works; (d) With only seven cover classes, the scale is better than the Domin scale (10 cover classes) in mitigating the indecisions that can occur when the initial cover estimate lies at the borderline between two cover classes (Hurford and Schneider 2007). Table 2 illustrates all the other changes made to the original Tzoulas-James Method and the reasons for these 
Table 1 Modified Tzoulas-James method (adapted from Tzoulas and James (2009))

\begin{tabular}{lll}
\hline Vegetation layer & Height range (m) & Expected Vegetation type \\
\hline 1. Upper canopy & $>9$ & Needle-leaf, broadleaf and mixed \\
2. Lower canopy & 4.1 to 9.0 & Needle-leaf, broadleaf and mixed \\
3. Bush (woody) & 0.51 to 4.00 & Shrub, scrub and hedgerow \\
$\begin{array}{l}\text { 4. Low bush and long grass } \\
\text { (non-woody) }\end{array}$ & 0.2 to 0.5 & Different types of grasses and forbs \\
$\begin{array}{l}\text { 5. Cropped or mowed grass } \\
\text { 6. Ground flora }\end{array}$ & 0.05 to 0.19 & Different types of cropped or mowed grasses and forbs \\
7. Open water & $<0.05$ & Bare ground, bryophytes, fungi, lichens and algae \\
8. Emergent hydrophytes & Not defined. & Possible submerged plants in shallow areas \\
9. Floating hydrophytes & Not defined. & Plants with base either temporarily or permanently submerged in water \\
10. Built & Not defined. & Mants with stomata that floats on water (excluding algae)
\end{tabular}

changes to adapt this method for SuDS application. No information of relevance to SuDS got lost during the adaptation process.

\section{Procedure for collecting vegetation structure cover-abundance data}

After the vegetation structure cover-abundance data collection method was developed, the procedure for collecting data was devised. The first step was a desk study to gather basic site information (area of site, site perimeter, site location and broad vegetation types) using Ordnance Survey maps and Google Earth satellite images. As an example, Fig. 1a shows an aerial photograph of one of the study sites (Castle Irwell), which conveys broad vegetation types (trees and grasses) that can be found on-site. According to the figure, grass dominated the site, and trees were found at the edge of the site and also in one or two small areas within the middle of the site. There was also a "tree island" located near the centre-right of the site. The image shown in Fig. 1a was compared with the data gathered on-site.

The second step was to establish sampling areas for data collection: $50 \mathrm{~m}$ by $50 \mathrm{~m}$ square $\left(2500 \mathrm{~m}^{2}\right)$ were used as the minimum sampling plot size for large sites $\left(>2500 \mathrm{~m}^{2}\right)$. Small sites $\left(\leq 2500 \mathrm{~m}^{2}\right)$ were surveyed in their entirety, assuming $100 \%$ coverage. For large sites, Ordnance Survey maps and Google Earth satellite images were used to randomly allocate $50 \mathrm{~m}$ by $50 \mathrm{~m}$ square sampling plots before surveys were

Table 2 Summary of other changes made to the Tzoulas-James method (Tzoulas and James 2009)

\begin{tabular}{|c|c|c|}
\hline Amendment & Detail & Reason \\
\hline Sampling area & $\begin{array}{l}\text { Changed from circular sample areas to a standard } \\
50 \mathrm{~m} \text { by } 50 \mathrm{~m} \text { plot. }\end{array}$ & $\begin{array}{l}\text { Improvement of the visual determination of the sample area boundary; } \\
\text { therefore, improvement of the on-site visual estimates of vegetation } \\
\text { percentage cover. }\end{array}$ \\
\hline $\begin{array}{l}\text { Vegetation layer } \\
\text { height range } \\
\text { changes }\end{array}$ & $\begin{array}{l}\text { Lowered the maximum height of the first layer } \\
\text { (upper canopy) from } \geq 10 \mathrm{~m} \text { to }>9 \mathrm{~m} \text {, and } \\
\text { subsequent adjustments of height ranges to other } \\
\text { layers (e.g., the lower canopy range from } 5.0 \mathrm{~m} \text { to } \\
9.9 \mathrm{~m} \text { was altered to } 4.1 \mathrm{~m} \text { to } 9.0 \mathrm{~m} \text { ) }\end{array}$ & $\begin{array}{l}\text { The majority of the vegetated sustainable drainage system (SuDS) } \\
\text { sites are situated in urban areas, which are not comparable with } \\
\text { those areas for which the design of the Tzoulas-James method was } \\
\text { originally based on (i.e. local area reserves with mature trees of } \\
\geq 10 \mathrm{~m} \text { high). Therefore, the height ranges were adjusted to reflect } \\
\text { upon the characteristics of urban vegetated SuDS sites. }\end{array}$ \\
\hline $\begin{array}{l}\text { Vegetation layer } \\
\text { reclassification }\end{array}$ & $\begin{array}{l}\text { Reclassified the first five layers to upper canopy, } \\
\text { lower canopy, bush (woody), low bush and long } \\
\text { grass (non-woody), and cropped or mowed grass }\end{array}$ & $\begin{array}{l}\text { To make a distinction between woody and non-woody plants of } \\
\text { similar heights, and to reflect upon the degree of management } \\
\text { performed on vegetated SuDS systems. }\end{array}$ \\
\hline $\begin{array}{l}\text { Vegetation layer } \\
\text { expansion }\end{array}$ & $\begin{array}{l}\text { Introduced open water, emergent hydrophytes and } \\
\text { floating hydrophytes as the eighth, ninth and tenth } \\
\text { layers. }\end{array}$ & $\begin{array}{l}\text { SuDS ponds contain different types of meso-habitats (submerged } \\
\text { vegetation is assumed to lie beneath open water). These are areas of } \\
\text { habitat within a pond that can form ecological niches for } \\
\text { invertebrates and vertebrates (Biggs et al. 1998; Offwell Woodland } \\
\text { and Wildlife Trust 1998; Raven et al. 1998; Howard 2002; PondNet } \\
\text { 2013). Emergent plants are more tolerant to pollution than } \\
\text { submerged plants; therefore, identifying and differentiating them } \\
\text { can aid habitat retention and incorporation into support for future } \\
\text { SuDS designs (Woods-Ballard et al. 2015). }\end{array}$ \\
\hline
\end{tabular}


Fig. 1 Castle Irwell (a) satellite image (Google 2015); and (b) site and sample plots (Crown Copyright/Database Right 2013; an Ordnance Survey/EDINA supplied service)

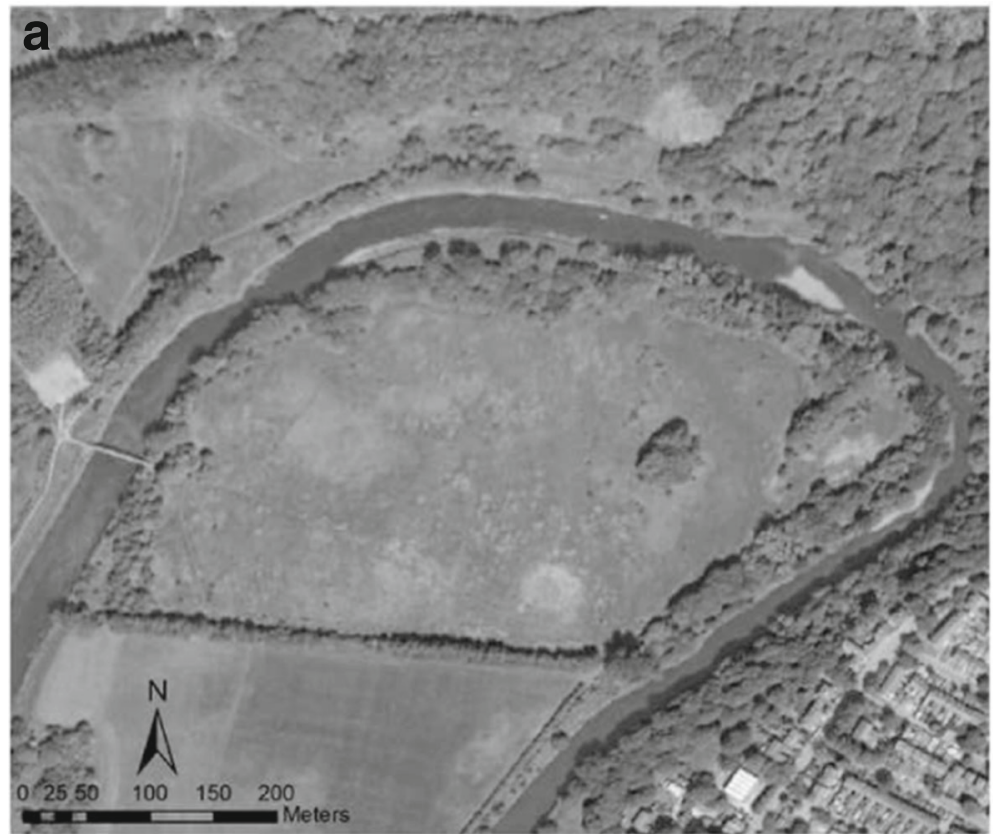

b

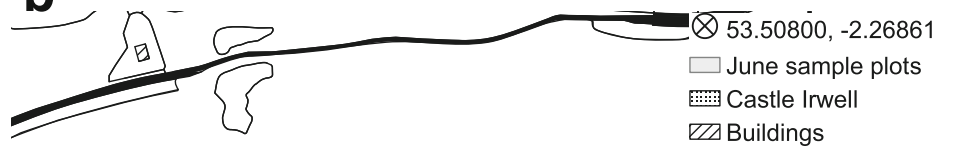

\section{$\square$ Land}

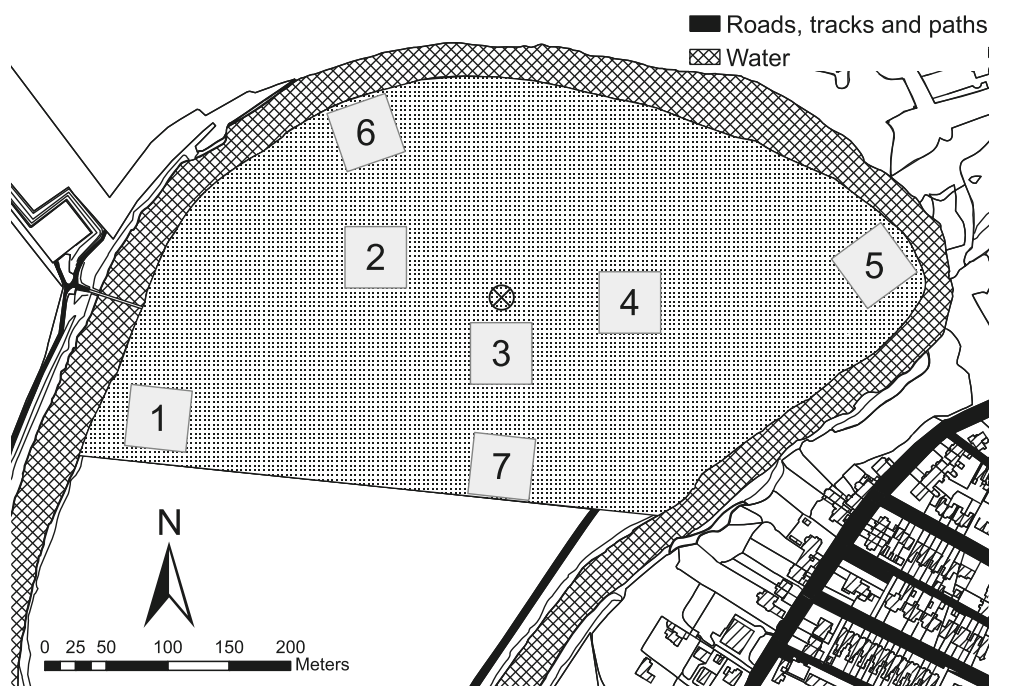

carried out on-site. A degree of structure was also introduced when deciding where to place the sample plots to ensure that key features were not missed.

As an example, Fig. 1b illustrates an annotated Ordnance Survey map which details the sampling plots employed for collecting vegetation structure cover-abundance data at Castle Irwell in June 2014. Guided by the satellite image (Fig. 1a), seven $2500 \mathrm{~m}^{2}$ sample plots were placed on the map for data collection. These sample plots covered all the essential features of the Castle Irwell site. Figure $1 \mathrm{~b}$ also allowed for coordinates of the sample plots to be extracted.
These coordinates guided the setting-up of the sample plots on-site. Both Google Earth satellite images and Ordnance Survey maps were used as desk survey tools for every sites surveyed during the research.

At the start of every site survey, the Ordnance Survey coordinates were verified and adjusted using a Garmin Etrex handheld Global Positioning System (GPS) device. For large sites, such as Castle Irwell, the four corners and the mid-point of the sample plots were marked out using distinctive bamboo canes (highlighting boundaries) to enable easier visual identification of the vegetation layers within the sample plots. 
Bamboo canes were not employed for small sites as they were surveyed in their entirety, assuming $100 \%$ coverage.

After the sample areas were established, the third step of the data collection procedure was to visually identify the vegetation layers on-site. The upper canopy layer (Table 1) was distinguished from the lower canopy layer (Table 1) using the Smart Measure function within the Smart Tools Android App (Android Boy 2010). This is a mobile phone application to measure the relative height of trees (Dianyuan and Chengduan 2011). Afterwards, estimates of the percentage cover of each vegetation layer were made (and noted down) from the centre point (if view the view was uninterrupted) or during a walk covering the sample area. Subsequently, Google Earth satellite images were used in 2015 to verify the accuracy of the estimates and to make necessary adjustments. The total percentage cover sum of all the vegetation layers can be above $100 \%$, because there will be overlaps of vegetation layers (e.g., plants growing beneath tree canopies). After the percentage cover data were confirmed, the forth step was to match the percentage cover with the corresponding Braun-Blanquet values, based on the Braun-Blanquet scale. These Braun-Blanquet values were used to work out habitat for species and carbon sequestration ecosystem services scores.

\section{Combining vegetation structure cover-abundance data into ecosystem services scores}

A simple and novel scoring procedure was created for estimating the potential of a site to generate habitat for species ecosystem service, using the vegetation structure coverabundance data collected on-site (Fig. 2a). This scoring procedure is based on the theory of succession and ecological niche. The first step of the scoring procedure as illustrated in Fig. 2a implies that every vegetation layer illustrated in Table 1 has a potential to be colonised by organisms. Therefore, one point was awarded for every vegetation layer observed on-site.

The second step assumes the contribution to biodiversity for vegetation layers one to nine is the same. For instance, the biodiversity value for $100 \%$ of upper canopy layer coverage is assumed to be the same as the biodiversity value for $100 \%$ of the lower canopy coverage, $100 \%$ of bush (woody) coverage, $100 \%$ of low bush and long grass (non-woody) coverage, $100 \%$ of cropped or mowed grass coverage, $100 \%$ of ground flora coverage, $100 \%$ of open water coverage, $100 \%$ of emergent hydrophytes coverage, or $100 \%$ of floating hydrophytes coverage. Therefore, the scoring procedure illustrated in Fig. 2a makes no distinction between which vegetation species occupies the site.

The third step assumes that the biodiversity potential for built surfaces (e.g., roads and buildings) is less than the biodiversity potential for vegetated surfaces or aquatic bodies (Tzoulas and James 2009). This is because a large built-up

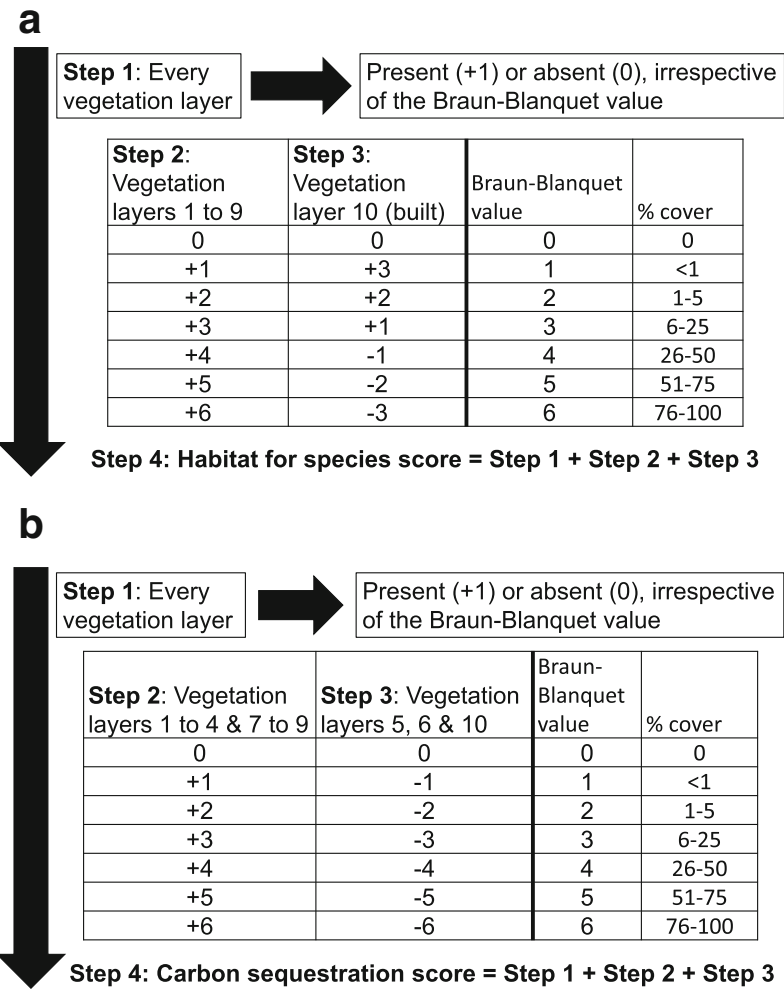

Fig. 2 Scoring procedure for (a) the habitat for species; and (b) the carbon sequestration variables using the vegetation structure coverabundance data

area is deemed to hold back succession (Godefroid and Koedam 2007), since built surfaces tend to be impermeable. Impermeable surfaces do not allow for water to infiltrate and do not allow plants to develop roots and colonise the surface. Therefore, no succession can take place. A decision, therefore, was taken to assign a negative score for when the category Built covers more than $25 \%$ of the site. This means that for a site to have a built surface that is more than $25 \%$ of the entire site, the habitat for species value of the site will fall. A positive score was given to the built layer that was observed to be $25 \%$ or less on-site. Similarly, the scoring procedure was constructed so that no negative scores can occur (Tzoulas and James 2009).

The fourth step combines steps 1 to 3 , which results in a score reflecting upon the habitat for species ecosystem service potential of the site. As an example, Table 3 contains the mean Braun-Blanquet values for the vegetation structure percentage cover data collected from the seven sample plots at Castle Irwell and illustrates the application of the habitat for species scoring procedure.

Similar to the procedure for calculating habitat for species scores, Fig. $2 \mathrm{~b}$ contains the scoring procedure for estimating the carbon sequestration ecosystem service potential of a site, using the same vegetation structure cover-abundance data collected on-site. Importantly, the scoring procedure only takes account of live above-ground biomass and can only provide 
Table 3 Habitat for species score for the Castle Irwell case study

\begin{tabular}{|c|c|}
\hline Vegetation layers & Mean BB values \\
\hline 1. Upper canopy (UC) & 3 \\
\hline 2. Lower canopy (LC) & 2 \\
\hline 3. Bush (woody) (BW) & 2 \\
\hline 4. Low bush and long grass (non-woody) (LBLG) & 5 \\
\hline 5. Cropped or mowed grass (CMG) & 1 \\
\hline 6. Ground flora (GF) & 0 \\
\hline 7. Open water $(\mathrm{OW})$ & 0 \\
\hline 8. Emergent hydrophyte (EH) & 0 \\
\hline 9. Floating hydrophyte (FH) & 0 \\
\hline 8. Built (BT) & 0 \\
\hline Step 1: (+1 for every layer present, irrespectively of BB value) & $+1+1+1+1+1=+5$ \\
\hline $\begin{array}{l}\text { Step } 2:(\mathrm{BB} \text { value for } \mathrm{UC}=3 \text {, therefore }+3 ; \mathrm{BB} \text { value for } \mathrm{LC}=2 \text {, } \\
\text { therefore }+2 ; \mathrm{BB} \text { value for } \mathrm{BW}=2 \text {, therefore }+2 ; \mathrm{BB} \text { value for } \mathrm{L} \\
\mathrm{BLG}=5 \text {, therefore }+5 ; \mathrm{BB} \text { value for } \mathrm{CMG}=1 \text {, therefore }+1 ; \mathrm{BB} \\
\text { values for } \mathrm{GF}, \mathrm{OW}, \mathrm{EH} \text { and } \mathrm{FH}=0 \text {, therefore } 0)\end{array}$ & $+3+2+2+5+1+0+0+0+0=+13$ \\
\hline Step 3: $(\mathrm{BB}$ value for $\mathrm{BT}=0$; therefore 0$)$ & 0 \\
\hline Step 4: (Sum of steps 1 to 3 ) & $+5+13+0=18$ \\
\hline
\end{tabular}

See Fig. 3 for details on the scoring procedure. $\mathrm{BB}=$ Braun-Blanquet an approximate indication of the potential carbon sequestration the site can provide. This is because the scoring procedure does not take account of other carbon pools such as living below-ground biomass, dead organic matter in wood, dead organic matter in litter, soil organic matter, wood products and landfills (Watson et al. 2000).

The first step of the scoring procedure illustrated in Fig. 2b again implies that every vegetation layer (Table 1) has a potential to be colonised by vegetation species; therefore, it can potentially sequester carbon via photosynthesis. Consequently, one point was awarded for every vegetation layer observed on-site.

The second step assumes vegetation layers 1 to 4,7 and 9 to contribute to carbon sequestration via photosynthesis, accumulation of organic carbon or sediment organic carbon accumulation in waterbodies.

The third step assumes vegetation layer 5 (cropped or mown grass) to consist entirely of heavily maintained turf grass. Therefore, this vegetation layer was given a negative score for carbon sequestration (Fig. 2b). This step of the scoring procedure also assumes vegetation layer 6 (ground flora) to consist entirely of primary succession species such as lichens (found on surfaces with harsh conditions such as roofs). They are assumed to have no carbon sequestration contribution towards the site being examined (Heim and Lundholm 2014; Douglas and James 2015). Similarly, the vegetation layer ten (built) does not contribute to carbon sequestration of the site, because no vegetation currently occupies it.

The fourth step combines steps 1 to 3 . This results in a score that reflects the carbon sequestration ecosystem service potential of the site.

\section{Cultural ecosystem services and disservices variables appraisal method}

Aside from the vegetation structure cover-abundance examination explained earlier, a cultural ecosystem services and disservices variables appraisal method was created to facilitate initial site and development characteristic surveys of potential vegetated SuDS sites. This appraisal method examines the recreation and education ecosystem services, and identifies possible ecosystem disservices the site can generate. Tables 4 illustrate the cultural ecosystem services and disservices variable appraisal method.

There are several variables detailed in Table 4 that require further clarification:

(1) The legal accessibility variable ranking is in accordance with the standards from the Countryside and Rights of Way Act 2000 (Natural England 2015).

(2) The ranking for the evidence of educational use variable is based on evidence of educational activities organised by community organisations (e.g., Friends of Groups, community forests and other similar local residents) and local councils.

(3) The approach to analyse the proximity of the closest education establishment variable follows the principle that no person should live further than $300 \mathrm{~m}$ from their nearest area of natural greenspace of at least two hectares in size (English Nature 2003; Natural England 2010). However, due to the small size of the sites chosen for the research, the standard for outdoor recreational facilities for children published by Fields in Trust and the 


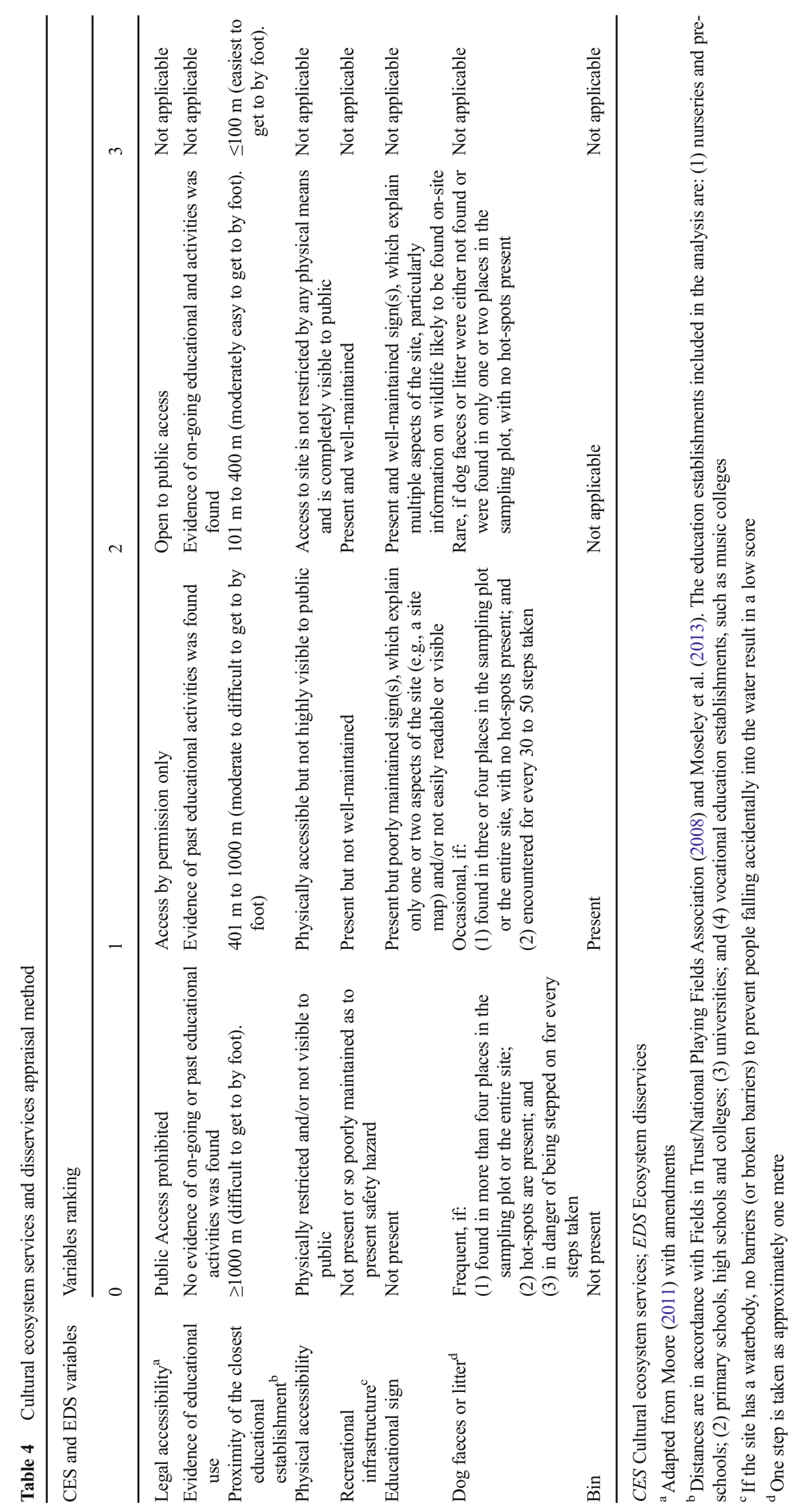


National Playing Fields Association ( 2008) was adopted instead of the English Nature's standard. Therefore, using Google Earth's buffering tool, the variable ranking distances detailed in Table 5 are turned into separate buffers, and the distance is determined using Google Earth's distance measuring tool. The shortest straight line distance measured from the closest education establishment to the site (represented using a polygon) is used to establish the site's ranking for this variable.

(4) The physical accessibility variable ranking is based on how much site accessibility is being physically hindered by barriers (e.g., fence, steep embankment, dense vegetation) and how visible the site is to the public. For example, a site can be at an out-of-sight location, behind buildings, behind dense understory, or situated a distance above ground, and still get a positive ranking (one point), because it is physically accessible.

(5) The recreational infrastructures variable ranking is based on the appraisal of facilities adjacent to sites (e.g., football pitches, athletics grounds and allotments) as well as on-site facilities (footpaths, wildlife viewing areas and benches).

(6) The dog faeces and litter variables ranking is based on dog faeces and litter coverage data collected using the same $2500-\mathrm{m}^{2}$ standard sampling plot employed for the vegetation structure cover-abundance survey. If the site is smaller than $2500 \mathrm{~m}^{2}$, it is surveyed in its entirety, assuming $100 \%$ coverage. The number of dog faeces and items of litter encountered on-site are not recorded. Additionally, adequate considerations should be given to sites with litter lying amongst dense understory or floating on the water surface (e.g., more than four items found should be given zero points) and a hot-spot on-site means concentration of litter beside bins or gathered by the sides of a pond.

(7) The legal accessibility, physical accessibility and recreational infrastructure variables are combined to generate a recreation score. Additionally, the educational signs, proximity of the closest educational establishment, and the evidence of educational use variables are combined to generate an education score. In contrast, the dog faeces, litter and bin variables are used for ecosystem disservices analysis.

Aside from vegetation structure cover-abundance analysis, Castle Irwell was also subjected to the cultural ecosystem services and disservices variables appraisal. Table 5 contains details of the cultural ecosystem services and disservice variables appraisal for Castle Irwell, which was previously part of the old Manchester Racecourse. But at the time of the survey, it was a place where people walked and enjoyed the local nature (Gardiner et al. 1998; Irwell Valley Sustainable
Communities Project 2014). The wooden benches found onsite (Table 5), therefore, allow walkers to sit and relax whilst surrounded by nature.

Combining the ranking for legal accessibility, physical accessibility and recreational infrastructures (Table 5) enables the recreation score for Castle Irwell to be calculated, which is four. Similarly, combining the ranking for educational signs, proximity of the closest education establishment, and evidence of educational use (Table 5) enables the education score to be calculated, which is also four.

Examining the Castle Irwell site alone, there is an indication that litter coverage was affected by having no litter bins on-site because litter coverage was observed to be frequent (Table 5). However, no dog faeces were observed on-site.

\section{Results linked to the application of the new methodology}

Habitat for species and carbon sequestration ecosystem services were calculated for all 49 sites using the raw data contained within Tables A2 and A3 within the supplementary material. Afterwards, an analysis was conducted to examine the relationships between the size of site (large: $>5500 \mathrm{~m}^{2}$, or small: $\leq 5500 \mathrm{~m}^{2}$ ), type of site (aquatic: sites with permanent water bodies and/or have aquatic vegetation present on-site; or terrestrial: sites with no water bodies or any aquatic vegetation present on-site) and the habitat for species scores. A similar analysis was carried out for the carbon sequestration scores. Figures $3 a$ and $b$ illustrate the plots of mean habitat for species scores and mean carbon sequestration scores against type of site for large and small sites, respectively. According to the data in Figs. 3a and b, aquatic sites generated higher habitat for species and carbon sequestration scores compared with terrestrial sites, with large aquatic sites generating the highest mean scores (33 for habitat for species and 22 for carbon sequestration).

Additionally, all 49 sites were examined for their cultural ecosystem services and disservices potentials by ranking each site based on the nine cultural variables (Tables 4). The summary of the ranking received for each site regarding the nine variables are presented in Table A4 within the supplementary material.

There were several analysis performed using the data in Table A4. Firstly, legal accessibility, physical accessibility and recreational infrastructure were combined to form recreation scores for all 49 sites and analysis was performed to examine whether there is a relationship between the recreational scores and the habitat for species scores. Secondly, educational signs, evidence of educational use and proximity of educational establishments were combined to form education scores for all 49 sites and analysis was performed to examine whether there is a relationship between the educational scores 
Table 5 Cultural ecosystem service and disservice variable appraisal results for Castle Irwell (case study site)

\begin{tabular}{|c|c|c|}
\hline Variable & Ranking & Reason \\
\hline Legal accessibility & 2 & At the time of survey, Salford City Council owned the site; therefore, there was no restriction to access. \\
\hline Physical accessibility & 1 & $\begin{array}{l}\text { The site is situated behind the Castle Irwell Student Village The University of Salford) and, therefore, } \\
\text { the site is not visible to the general public. The site can be accessed from the student village via a } \\
\text { small gap between the trees at the south-east boundary of the site, and access to the site by the general } \\
\text { public was provided by a footbridge crossing the River Irwell at the west of the site. }\end{array}$ \\
\hline Recreational infrastructure & 1 & $\begin{array}{l}\text { Footpaths are provided by differential mowing, apart from a dirt track linking the footbridge to the actual } \\
\text { site. Three to four wooden benches were also found on-site. }\end{array}$ \\
\hline Educational signs & 0 & There was no educational sign present on-site. \\
\hline $\begin{array}{l}\text { Proximity of the closest } \\
\text { education establishment }\end{array}$ & 2 & $\begin{array}{l}\text { The closest educational establishment to the site is Brentnall Primary School }(278 \mathrm{~m}) \text {. The Castle Irwell } \\
\text { Student Village is not an educational establishment. }\end{array}$ \\
\hline Evidence of educational use & 2 & $\begin{array}{l}\text { The Irwell Valley Sustainable Communities Project is an ongoing community project that is designed to support } \\
\text { local residents to adapt to climate change and live more sustainably (Irwell Valley Sustainable Communities } \\
\text { Project 2014). The project's website also details Castle Irwell's proposed transformation from a recreational } \\
\text { grassland to a sustainable flood retention basin as part of the River Irwell flood mitigation strategy } \\
\text { (Irwell Valley Sustainable Communities Project 2014). Gardiner et al. (1998) has written about the site in t } \\
\text { heir fieldwork guide to Greater Manchester. }\end{array}$ \\
\hline Dog faeces & 2 & Rare (none observed). \\
\hline Bin & 0 & Not present. \\
\hline Litter & 0 & $\begin{array}{l}\text { Frequent: Litter was found at more than four places within each sample plot and litter was also encountered } \\
\text { for every few steps (less than 30) taken whilst walking within the sample plots. }\end{array}$ \\
\hline
\end{tabular}

and the habitat for species scores. Finally, the data for coverage of dog faeces and litter on-site, and the data for the presence of bins were tabulated and analysed to investigate the relationships between these variables. The scores and the analysis can be found in Tables A5, A6 and A7 within the online supplementary material.

The results of the analysis on recreational scores versus habitat for species scores indicate that sites with higher recreational scores tend to achieve higher habitat for species scores, or vice versa. Unfortunately, the results of the analysis on educational scores versus habitat for species scores suggest that there is no significant $(p<0.05)$ influence between these two ecosystem services, out of the 49 sites surveyed. Finally, the results of the analysis regarding the relationships between dog faeces, litter and waste bins suggest that the presence of bins on-site contributed to the reduction of dog faeces and litter coverage.

\section{Discussion of the new methodology}

The vegetation structure cover-abundance examination method presented in this paper is based on the findings from previous vegetated SuDS systems and urban green space studies. These previous results confirm that a diverse vegetation structure enhances urban habitat heterogeneity and is also a major factor that positively influences habitat resources for invertebrates (Hercock 1997; Hermy and Cornelis 2000; Savard et al. 2000; Fernández-Juricic and Jokimäki 2001; Young and Jarvis 2001; Honnay et al. 2003; Livingston et al. 2003;
Cornelis and Hermy 2004; Jackson and Boutle 2008; Tzoulas and James 2009; Viol et al. 2009; Dvorak and Volder 2010; Coffman and Waite 2011; Kazemi et al. 2011; Moore 2011; Moore and Hunt 2012; Iswoyo et al. 2013; Briers 2014; Beumer and Martens 2015; Van Mechelen et al. 2015; Voigt and Wurster 2015). Consequently, vegetation structure diversity in vegetated $\mathrm{SuDS}$ systems has a key role to play in offering more resources and opportunities to different organisms within an ecosystem, which is compatible with the ecological niche theory (Cain et al. 2011).

Whilst biodiversity analysis can involve examination of many different variables (Jackson and Boutle 2008; Viol et al. 2009; Kazemi et al. 2011; Moore and Hunt 2012; Briers 2014; Rooney et al. 2015), the vegetation structure cover-abundance examination allows coarse-scale assessments to be made, providing information on biodiversity and subsequent ecosystem services of an area (Iswoyo et al. 2013; Scholz and Uzomah 2013; Peh et al. 2013; Uzomah et al. 2014; Voigt and Wurster 2015).

However, there is criticism stating that cover-abundance analysis is too subjective for biodiversity research (Poore 1955; Podani 2006). Subjectivity is a shortcoming of all the methods detailed in this paper, but a balance must be struck between accuracy, efficiency, speed of survey and costs (Scholz and Uzomah 2013). When an ecosystem services analysis is required before a development decision can be made, rapid, accurate and cost-effective methods are needed to enable good planning decisions to be made (Scholz and Uzomah 2013). Utilising vegetation structure coverabundance and cultural ecosystem services and disservices 

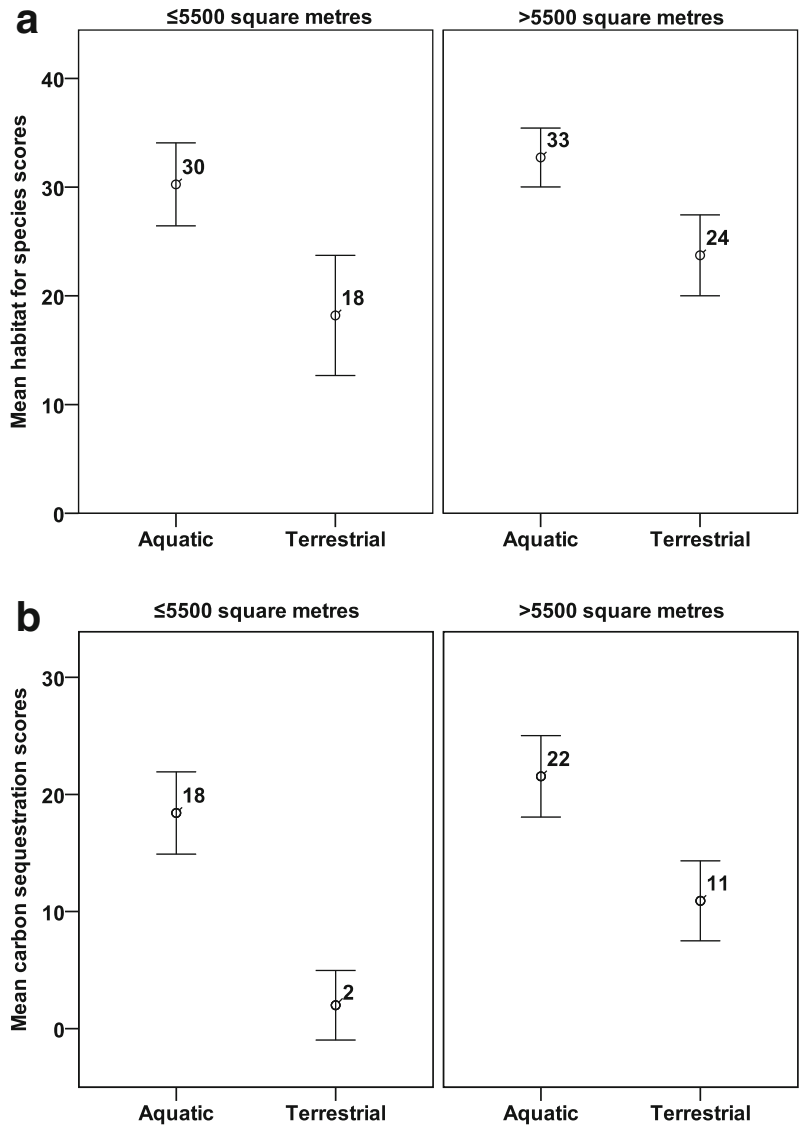

Fig. 3 Plots for (a) mean habitat for species; and (b) carbon sequestration scores against type of site for small and large sites. Note: Error bars $= \pm 2$ standard errors

variables for analysis is a trade-off between accuracy and cost-effectiveness and is deemed to be acceptable in terms of enabling development planning decisions to be made. The proposed simplified and generic methods should be applicable to various countries and will not necessarily replace other more detailed and established methods, but should aid stakeholders in making formal and legal planning decisions.

Conducting vegetation structure cover-abundance surveys without species identification is not the standard way of conducting phytosociological studies, and there is criticism towards the use of the Braun-Blanquet scale in this field of study (Poore 1955; Podani 2006). On the other hand, the aim of this research is not to analyse any specific vegetation species in a phytosociological way and the modified Tzoulas-James method was not employed for use in phytosociological studies. Therefore such criticism is irrelevant for the way this research was performed, which focuses on the analyses of vegetation structure in the broadest sense to give an appreciation of the biodiversity-driven ecosystem services a site can generate.

Overall, the four ecosystem services chosen (habitat for species, carbon sequestration, recreation and education) reflect upon the biodiversity and amenity potential of the new
SuDS approach (Woods-Ballard et al. 2015). Habitat for species was chosen because vegetated SuDS systems can be ideal places of habitats for many native animals and plant species (acting as sanctuaries for separated aquatic and wetland macroinvertebrates), and they in turn contribute to the overall biodiversity of the urban environment (Jackson and Boutle 2008; Viol et al. 2009; Dvorak and Volder 2010; Moore 2011; Moore and Hunt 2012; Rowe et al. 2012; Briers 2014; Cao et al. 2014; Scholz 2015). Overall, vegetated SuDS schemes, especially when incorporated into existing urban green infrastructures, can contribute to the reconnection of fragmented habitats (Natural England 2011; Ellis 2013; Graham et al. 2013; Scholz 2015).

Carbon sequestration was chosen because vegetated SuDS sites can contribute to biological carbon sequestration by acting as sinks that store carbon as above-ground (mature trees) and below-ground (soil organic matter) biomass. Mature trees have plenty of biomass accumulated and experience little net growth, making the changes in that stock (flux) very small or even zero (Perry 1998; Waran 2001). Soil organic matter is made-up of different forms of carbon and nutrients such as carbohydrates, proteins, fats and nucleic acids (Logan and Longmore 2011). Carbon sequestration via soil organic matter accumulation is best demonstrated by storm water ponds (Downing et al. 2008; Boyd et al. 2010; Downing 2010; Adhikari et al. 2012; Moore and Hunt 2013; Pittman et al. 2013; Scholz 2015).

With regard to the third step of the habitat for species scoring procedure (Fig. 2a), the built layer that was observed to be $25 \%$ or less on-site was given a positive score. This is because impermeable materials (e.g. pavements and walls) can also provide habitats for species, as long as it has time to accumulate moisture, is exposed to sunlight and has time for substrates to accumulate (Scholz and Grabowiecki 2007; Douglas and James 2015). A small amount of built cover amongst other vegetation, therefore, can act as areas for species involved in primary succession to colonise. Concurrently, the reason for deliberately designing the scoring procedure so that negative scores would never occur is because minimal vegetation amongst impermeable materials (e.g. $99.9 \%$ built, $0.1 \%$ vegetation) can still support habitats or the conditions for habitat to survive.

Alternatively, with regard to the third step of the carbon sequestration scoring procedure in Fig. 2b, the assignment of a negative score is due to the management requirements (heavy water use for irrigation, use of fertilisers and pesticides, and constant mowing) of turf grass. Therefore, the carbon sequestration capacity of turf grass-based SuDS systems cannot mitigate against greenhouse gas emission in urban areas (Milesi et al. 2005; Townsend-Small and Czimczik 2010), even though turf grass itself can sequester carbon (Milesi et al. 2005).

Aside from the biodiversity-related ecosystem services, vegetated SuDS systems can also provide recreation and 
education opportunities, which are vital to amenity provision. These opportunities were found to depend upon various drivers such as legal accessibility, recreational infrastructure, history of educational use and educational infrastructure (Moore and Hunt 2012). Other major factors that can maximise recreational and educational ecosystem services of vegetated SuDS systems are public exposure, public participation and the provision of educational information signs (Krasny et al. 2014; Church 2015; Feinberg et al. 2015; Hansen et al. 2015).

\section{Conclusions and further research}

In this paper, two novel cost-effective, rapid, reliable and nonexpert methods for carrying out initial biodiversity and amenity site and development characteristic surveys were presented. These two methods (vegetation structure cover-abundance examination and cultural ecosystem services and disservices appraisal) are ecosystem approach compliant, which is in line with the new SuDS manual. Therefore, the two methods can assist in the design of SuDS systems that can contribute to the ecological resilience of ecosystems.

The ecosystem services scores produced using the two methods presented in this paper with the help of an example case study can also be used as quality indicators to rank sites based on the biodiversity- and amenity-related benefits they can offer. This will allow SuDS retrofit site selection decisions to be made that consider biodiversity and amenity as well as drainage issues. Overall, the two methods will allow planners, developers and designers to save time and money when planning and designing SuDS systems, and will enable future $\mathrm{SuDS}$ retrofit designs to be more wildlife-friendly and socially inclusive.

The authors recommend the development and testing of similar methods for the determination of even softer (from an engineering perspective) ecosystem services variables including aesthetics and sense of place. Such variables are often ignored by planners, developers and engineers, because they are difficult to quantify. However, some of these variables are often decisive in terms of public acceptance of a new SuDS scheme.

Acknowledgments The authors thank the Engineering and Physical Sciences Research Council of the United Kingdom for supporting the lead author with a studentship. Konstantinos Tzoulas kindly demonstrated the use of the original Tzoulas-James Method to the authors. Ruqayah Mohammed supported the preparation of the figures.

Open Access This article is distributed under the terms of the Creative Commons Attribution 4.0 International License (http:// creativecommons.org/licenses/by/4.0/), which permits unrestricted use, distribution, and reproduction in any medium, provided you give appropriate credit to the original author(s) and the source, provide a link to the Creative Commons license, and indicate if changes were made.

\section{References}

Adhikari S, Lal R, Sahu BC (2012) Carbon sequestration in the bottom sediments of aquaculture ponds of Orissa, India. Ecol Eng 47:198-202

Android Boy (2010) Smart Measure Pro (ver 2.4) manual. http://androidboy1.blogspot.kr/2010/10/smart-measure-ver-20manual.html. Accessed 18 February 2016

Ashton R, Baker R, Dean J, Golshetti G, Jaluzot A, Jones N, Moss M, Steele M, Williams W, Wilmers P (2010) Building natural value for sustainable economic development: The green infrastructure valuation toolkit user guide. Green Infrastructure North West, Manchester

Astaraie-Imani M, Kapelan Z, Fu G, Butler D (2012) Assessing the combined effects of urbanisation and climate change on the river water quality in an integrated urban wastewater system in the UK. J Environ Manag 112:1-9. doi:10.1016/j.jenvman.2012.06.039

Bastian O, Syrbe R-U, Rosenberg M, Rahe D, Grunewald K (2013) The five pillar EPPS framework for quantifying, mapping and managing ecosystem services. Ecosystem Services 4:15-24. doi:10.1016/j. ecoser.2013.04.003

Bates AJ, Sadler JP, Mackay R (2013) Vegetation development over four years on two green roofs in the UK. Urban For Urban Green 12:98 108. doi:10.1016/j.ufug.2012.12.003

Beumer C, Martens P (2015) Biodiversity in my (back)yard: towards a framework for citizen engagement in exploring biodiversity and ecosystem services in residential gardens. Sustain Sci 10:87-100. doi:10.1007/s11625-014-0270-8

Biggs J, Fox G, Nicolet P, Walker D, Whitfield M, Williams P (1998) A guide to the methods of the National Pond Survey. Pond Action, Oxford

Boyd J, Banzhaf S (2007) What are ecosystem services? The need for standardized environmental accounting units. Ecol Econ 63:616626. doi:10.1016/j.ecolecon.2007.01.002

Boyd CE, Wood CW, Chaney PL, Queiroz JF (2010) Role of aquaculture pond sediments in sequestration of annual global carbon emissions. Environ Pollut 158:2537-2540. doi:10.1016/j.envpol.2010.04.025

Brenneisen S (2006) Space for urban wildlife: designing green roofs as habitats in Switzerland. Urban Habitats 4:27-36

Briers RA (2014) Invertebrate communities and environmental conditions in a Series of Urban Drainage Ponds in Eastern Scotland: Implications for biodiversity and conservation value of SUDS. Clean: Soil, Air, Water 42:193-200. doi:10.1002/clen.201300162

Cain ML, Bowman WD, Hacker SD (2011) Ecology. Sinauer Associates, Inc, Sunderland

Cao CTN, Farrell C, Kristiansen PE, Rayner JP (2014) Biochar makes green roof substrates lighter and improves water supply to plants. Ecol Eng 71:368-374. doi:10.1016/j.ecoleng.2014.06.017

Carter JG, Cavan G, Connelly A, Guy S, Handley J, Kazmierczak A (2015) Climate change and the city: building capacity for urban adaptation. Prog Plan 95:1-66. doi:10.1016/j.progress.2013.08.001

Church SP (2015) Exploring green streets and rain gardens as instances of small scale nature and environmental learning tools. Landsc Urban Plan 134:229-240. doi:10.1016/j.landurbplan.2014.10.021

Coffman RR, Waite T (2011) Vegetated roofs as reconciled habitats: Rapid assays beyond mere species counts. Urban Habitats 6, 1

Cornelis J, Hermy M (2004) Biodiversity relationships in urban and suburban parks in Flanders. Landsc Urban Plan 69:385-401

Costanza R, d'Arge R, de Groot R, Farber S, Grasso M, Hannon B, Limburg K, Naeen S, O’Neill RV, Paruelo J, Raskin RG, Sutton P, van den Belt M (1998) The value of the world's ecosystem services and natural capital. Ecol Econ 25:3-15. doi:10.1016/S0921-8009 (98)00020-2

Daily GC, Alexander S, Ehrlich PR, Goulder L, Lubchenco J, Matson PA, Mooney HA, Postel S, Schneider SH, Tilman D, Woodwell GM 
(1997) Ecosystem services: benefits supplied to human societies by natural ecosystems. Issues in Ecology 2:1-16

de Groot RS, Wilson MA, Boumans RMJ (2002) A typology for the classification, description and valuation of ecosystem functions, goods and services. Ecol Econ 41:393-408

Department of Environment, Food and Rural Affairs (2012) Tackling water pollution from the urban environment - consultation on a strategy to address diffuse water pollution from the built environment. Defra, London

Dianyuan H, Chengduan W (2011) Tree height measurement based on image processing embedded in smart mobile phone. Paper presented at the 2011 International Conference on Multimedia Technology (ICMT). Institute of Electrical and Electronics Engineers, Hangzhou, pp. 3293-3296

Dickie S, McKay G, Ions L, Shaffer P (2010) CIRIA C687 Planning for SuDS - making it happen. Construction Industry Research and Information Association (CIRIA), London

Douglas I, James P (2015) Urban Ecology - An Introduction. Routledge, Abingdon

Downing JA (2010) Emerging global role of small lakes and ponds: little things mean a lot. Limnetica 29:9-24

Downing JA, Cole JJ, Middelburg JJ, Striegl RG, Duarte CM, Kortelainen P, Prairie YT, Laube KA (2008) Sediment organic carbon burial in agriculturally eutrophic impoundments over the last century. Glob Biogeochem Cycles 22:1-10. doi:10.1029/2006 GB002854

Dunn RR (2010) Global mapping of ecosystem disservices: the unspoken reality that nature sometimes kills us. Biotropica 42:555-557

Dvorak B, Volder A (2010) Green roof vegetation for north American ecoregions: a literature review. Landsc Urban Plan 96:197-213. doi:10.1016/j.landurbplan.2010.04.009

Ellis JB (2013) Sustainable surface water management and green infrastructure in UK urban catchment planning. J Environ Plan Manag $56: 24-41$

English Nature (2003) Accessible Natural Green Space Standards in Towns and Cities: A Review and Toolkit for their Implementation. English Nature, Peterborough

Environment Agency (2014) Water for life and livelihoods. A consultation on the draft update to the river basin management plan for the North West River Basin District - Part 1: Summary and consultation questions. Environment Agency, Bristol

Escobedo FJ, Kroeger T, Wagner JE (2011) Urban forests and pollution mitigation: analyzing ecosystem services and disservices. Environ Pollut 159:2078-2087

Feinberg DS, Hostetler ME, Reed SE, Pienaar EF, Pejchar L (2015) Evaluating management strategies to enhance biodiversity in conservation developments: perspectives from developers in Colorado, USA. Landsc Urban Plan 136:87-96. doi:10.1016/j. landurbplan.2014.12.002

Fernández-Juricic E, Jokimäki J (2001) A habitat island approach to conserving birds in urban landscapes: case studies from southern and northern Europe. Biodivers Conserv 10:2023-2043

Fields in Trust/National Playing Fields Association (2008) Planning and design for outdoor sport and play. Fields in Trust, London

Fisher B, Turner RK, Morling P (2009) Defining and classifying ecosystem services for decision making. Ecol Econ 68:643-653. doi:10.1016/j.ecolecon.2008.09.014

Fletcher TD, Shuster W, Hunt WF, Ashley R, Butler D, Arthur S, Trowsdale S, Barraud S, Semadeni-Davies A, Bertrand-Krajewski J-L, Mikkelsen PS, Rivard G, Uhl M, Dagenais D, Viklander M (2014) SUDS, LID, BMPs, WSUD and more - the evolution and application of terminology surrounding urban drainage. Urban Water J 12:525-542. doi:10.1080/1573062X.2014.916314

Gardiner A, Hindle P, McKendrick J, Perkins C (1998) Exploring greater Manchester - a fieldwork guide. Manchester Geographical Society, Manchester
Garroway CJ, Sheldon BC (2013) Urban behavioural adaptation. Mol Ecol 22(13):3430-3432. doi:10.1111/mec.12351

Godefroid S, Koedam N (2007) Urban plant species patterns are highly driven by density and function of built-up areas. Landsc Ecol 22: $1227-1239$

Gómez-Baggethun E, Barton DN (2013) Classifying and valuing ecosystem services for urban planning. Ecol Econ 86:235-245. doi:10.1016/j.ecolecon.2012.08.019

Google (2015) Castle Irwell. https://www.google.com/earth. Accessed 10 June 2015

Graham A, Day J, Bray B, Mackenzie S (2013) Sustainable drainage systems - maximising the potential for people and wildlife. A guide for local authorities and developers. WWT and RSPB, Slimbridge

Haines-Young R, Potschin M, Fish R (2012) Classifying Ecosystem Services - An EKN briefing paper. Paper presented at the Ecosystem Knowledge Network Briefing Paper No.1. http://ekn. defra.gov.uk/about/themes/classifying/briefing. Accessed 18 February 2016

Hansen R, Frantzeskaki N, McPhearson T, Rall E, Kabisch N, Kaczorowska A, Kain J-H, Artmann M, Pauleit S (2015) The uptake of the ecosystem services concept in planning discourses of European and American cities. Ecosystem Services 12:228-246. doi:10.1016/j.ecoser.2014.11.013

Hanson C, Ranganathan J, Iceland C, Finisdore J (2012) The corporate ecosystem services review: guidelines for identifying business risks and opportunities arising from ecosystem change, vol 2. World Resources Institute, Washington, DC

Heim A, Lundholm J (2014) Cladonia lichens on extensive green roofs: evapotranspiration, substrate temperature, and albedo. F1000Research 2:274

Hercock MJ (1997) Appreciating the biodiversity of remnant bushland: an 'architectural' approach. Environmentalist 17:249-258. doi:10.1023/A:1018593109738

Hermy M, Cornelis J (2000) Towards a monitoring method and a number of multifaceted and hierarchical biodiversity indicators for urban and suburban parks. Landsc Urban Plan 49:149-162

Honnay O, Piessens K, Landuyt WV, Hermy M, Gulinck H (2003) Satellite based land use and landscape complexity indices as predictors for regional plant species diversity. Landsc Urban Plan 63:241-250

Howard S (2002) A guide to monitoring the ecological quality of ponds and canals using PSYM. Environment Agency and Pond Conservation Trust: Policy \& Research, Oxford

Hurford C, Schneider M (2007) Monitoring nature conservation in cultural habitats: a practical guide and case studies. Springer, Berlin

Intergovernmental Panel on Climate Change (2007) Climate change 2007: impacts, adaptation and vulnerability. Intergovernmental Panel on Climate Change, Cambridge

Irwell Valley Sustainable Communities Project (2014) Take a Walk on Castle Irwell? http://www.greenmyvalley.com/2014/11/02/takewalk-castle-irwell. Accessed 21 July 2015

Iswoyo H, Vale B, Bryant M (2013) Scoring Urban Spaces in an Indonesian City Based on Biodiversity. Paper presented at the 2nd International Conference on Geological and Environmental Sciences, Singapore

Jackson JI, Boutle R (2008) Ecological functions within a sustainable urban drainage system. Paper presented at the 11th International Conference on Urban Drainage, Edinburgh

Jones JE, Guo J, Urbonas B, Pittinger R (2006) Essential Safety Considerations for Urban Stormwater Retention and Detention Ponds. Stormwater Magazine. Accessed 18 February 2016

Kazemi F, Beecham S, Gibbs J (2011) Streetscape biodiversity and the role of bioretention swales in an Australian urban environment. Landsc Urban Plan 101:139-148 
Kim K-G (2004) The application of the biosphere reserve concept to urban areas - the case of green rooftops for habitat network in Seoul. Acad Sci 1023:187-214

Krasny ME, Russ A, Tidball KG, Elmqvist T (2014) Civic ecology practices: participatory approaches to generating and measuring ecosystem services in cities. Ecosystem Services 7:177-186. doi:10.1016 /j.ecoser.2013.11.002

Ksiazek K, Fant J, Skogen K (2012) An assessment of pollen limitation on Chicago green roofs. Landsc Urban Plan 107(4):401-408

Limburg KE, Luzadis VA, Ramsey M, Schulz KL, Mayer CM (2010) The good, the bad, and the algae: perceiving ecosystem services and disservices generated by zebra and quagga mussels. J Great Lakes Res 36(1):86-92

Livingston M, Shaw WW, Harris LK (2003) A model for assessing wildlife habitats in urban landscapes of eastern Pima County, Arizona (USA. Landsc Urban Plan 64:131-144

Logan G, Longmore A (2011) Sediment organic matter and nutrients. Biophysical indicators. http://www.ozcoasts.gov. au/indicators/sediment_org_matter.jsp. Accessed 14 June 2015

Lyytimaki J, Sipila M (2009) Hopping on one leg - the challenge of ecosystem disservices for urban green management. Urban Forestry and Urban Greening 8:309-315

Lyytimaki J, Petersen LK, Normander B, Bezak P (2008) Nature as a nuisance? Ecosystem services and disservices to urban lifestyle. Environ Sci 5:161-172

Maltby E (2010) AS I SEE IT: effects of climate change on the societal benefits of UK upland peat ecosystems: applying the ecosystem approach. Clim Res 45:1-11

Milesi C, Running SW, Elvidge CD, Dietz JB, Tuttle BT, Nemani RR (2005) Mapping and modeling the biogeochemical cycling of turf grasses in the United States. Environ Manag 36:426-438

Millennium Ecosystem Assessment (2005) Ecosystems and human well-being synthesis. Millennium Ecosystem Assessment, Washington, DC

Moore TL (2011) Assessment of ecosystem service provision by storm water control measures. Doctor of Philosophy, North Carolina State University, Raleigh

Moore TLC, Hunt WF (2012) Ecosystem service provision by storm water wetlands and ponds - a means for evaluation? Water Res 46: $6811-6823$

Moore TLC, Hunt WF (2013) Predicting the carbon footprint of urban storm water infrastructure. Ecol Eng 58:44-51. doi:10.1016/j. ecoleng.2013.06.021

Moseley D, Marzano M, Chetcuti J, Watts K (2013) Green networks for people: application of a functional approach to support the planning and management of greenspace. Landsc Urban Plan 116:1-12

Natural England (2010) 'Nature Nearby' - Accessible Natural Greenspace Guidance. Natural England, Sheffield

Natural England (2011) Green Infrastructure Guidance. Natural England, Sheffield

Natural England (2015) Outdoor access and recreation guidance: open access land: management, rights and responsibilities. Natural England, Sheffield. https://www.gov.uk/guidance/open-accessland-management-rights-and-responsibilities. Accessed 10 February 2015

O'Farrell PJ, Anderson PML, Maitre DCL, Holmes PM (2012) Insights and opportunities offered by a rapid ecosystem service assessment in promoting a conservation agenda in an urban biodiversity hotspot. Ecol Soc 17:27

Oberndorfer E, Lundholm J, Bass B, Coffman RR, Doshi H, Dunnett N, Gaffin S, Kohler M, Liu KKY, Rowe B (2007) Green roofs as urban ecosystems: ecological structures, functions, and services. Bioscience 57:823-833

Offwell Woodland and Wildlife Trust (1998) Hydrosere - A wetland example of succession in action. http://www.countrysideinfo.co. uk/successn/hydro.htm. Accessed 11 March 2015
Peh KSH, Balmford A, Bradbury RB, Brown C, Butchart SHM, Hughes FMR, Stattersfield A, Thomas DHL, Walpole M, Bayliss J, Gowing D, Jones JPG, Lewis SL, Mulligan M, Pandeya B, Stratford C, Thompson JR, Turner K, Vira B, Willcock S, Birch JC (2013) TESSA: a toolkit for rapid assessment of ecosystem services at sites of biodiversity conservation importance. Ecosystem Services 5:5157. doi:10.1016/j.ecoser.2013.06.003

Perry DA (1998) The Scientific Basis of Forestry. Annu Rev Ecol Syst 29:435-466

Pitt M (2007) The Pitt Review: Lessons learned from the 2007 floods. Government of the United Kingdom, London

Pittman B, Jones JR, Millspaugh JJ, Kremer RJ, Downing JA (2013) Sediment organic carbon distribution in 4 small northern Missouri impoundments: implications for sampling and carbon sequestration. Inland Waters 3:39-46

Podani J (2006) Braun-Blanquet's legacy and data analysis in vegetation science. J Veg Sci 17:113-117

Polley L (2005) Navigating parasite webs and parasite flow: emerging and re-emerging parasitic zoonosis of wildlife origin. Int J Parasitol 35(11-12):1279-1294. doi:10.1016/j.ijpara.2005.07.003

PondNet (2013) Surveying for invertebrates. PondNet. http://www. freshwaterhabitats.org.uk/projects/pondnet/survey-packs. Accessed 02 September 2014

Poore MED (1955) The use of Phytosociological methods in ecological investigations: II. Practical issues involved in an attempt to apply the Braun-Blanquet system. The. J Ecol 43:245-269

Raven PJ, Holmes NTH, Dawson FH, Everard M (1998) Quality assessment using river habitat survey data. Aquatic conservation: marine and freshwater. Ecosystems 8:477-499

Rooney RC, Foote L, Krogman N, Pattison JK, Wilson MJ, Bayley SE (2015) Replacing natural wetlands with storm water management facilities: biophysical and perceived social values. Water Res 73:17-28

Rowe DB, Getter KL, Durhman AK (2012) Effect of green roof media depth on Crassulacean plant succession over seven years. Landsc Urban Plan 104:310-319. doi:10.1016/j.landurbplan.2011.11.010

Savard J-PL, Clergeau P, Mennechez G (2000) Biodiversity concepts and urban ecosystems. Landsc Urban Plan 48:131-142

Scholz M (2015) Wetlands for water pollution control, 2nd edn. Elsevier, Amsterdam

Scholz M, Grabowiecki P (2007) Review of permeable pavement systems. Build Environ 42:3830-3836

Scholz M, Uzomah VC (2013) Rapid decision support tool based on novel ecosystem service variables for retrofitting of permeable pavement systems in the presence of trees. Sci Total Environ 458:486-498

Scholz M, Uzomah VC, Almuktar SAAAN, Radet-Taligot J (2013) Selecting sustainable drainage structures based on ecosystem service variables estimated by different stakeholder groups. Water 5:1741-1759

Secretariat of the Convention on Biological Diversity (2004) The ecosystem approach. Secretariat of the Convention on Biological Diversity, Montreal

Semadeni-Davies A, Hernebring C, Svensson G, Gustafsson L-G (2008) The impacts of climate change and urbanisation on drainage in Helsingborg, Sweden: combined sewer system. J Hydrol 350:100-113

Shapiro J, Báldi A (2014) Accurate accounting: how to balance ecosystem services and disservices. Ecosystem Services 7:201-202

Sustainable Cities Institute (2012) Stormwater Management: Retention Ponds. http://www.sustainablecitiesinstitute.org/view/page. basic/class/feature.class/Lesson Retention Ponds Overview. Accessed 25 November 2013

Sutherland WJ (2006) Ecological Census Techniques - a handbook, 2nd Edition. Cambridge University Press

The Economics of Ecosystems and Biodiversity (2010) The economics of ecosystems and biodiversity report for business - executive summary 2010. TEEB, Wesseling, p. 27 
Tonietto R, Fant J, Ascher J, Ellis K, Larkin D (2011) A comparison of bee communities of Chicago green roofs, parks and prairies. Landsc Urban Plan 103:102-108

Townsend-Small A, Czimczik CI (2010) Carbon sequestration and greenhouse gas emissions in urban turf. Geophys Res Lett 37:L02707

Tzoulas K, James P (2009) Making biodiversity measures accessible to non-specialists: an innovative method for rapid assessment of urban biodiversity. Urban. Ecosystems 13:113-127. doi:10.1007/s11252009-0107-x

UK National Ecosystem Assessment (2011) UK National Ecosystem Assessment - Synthesis of the Key Findings. United Nations Environment Programme, World Conservation Monitoring Centre, Cambridge

UK National Ecosystem Assessment (2014) The UK National Ecosystem Assessment: Synthesis of the Key Findings. United Nations Environment Programme, World Conservation Monitoring Centre and Living With Environmental Change, Cambridge

Uzomah V, Scholz M, Almuktar S (2014) Rapid expert tool for different professions based on estimated ecosystem variables for retrofitting of drainage systems. Comput Environ Urban Syst 44:114

Van Mechelen C, Van Meerbeek K, Dutoit T, Hermy M (2015) Functional diversity as a framework for novel ecosystem design: the example of extensive green roofs. Landsc Urban Plan 136: 165-173. doi:10.1016/j.landurbplan.2014.11.022

Viol IL, Mocq J, Julliard R, Kerbiriou C (2009) The contribution of motorway storm water retention ponds to the biodiversity of aquatic macroinvertebrates. Biol Conserv 142:3163-3171
Voigt A, Wurster D (2015) Does diversity matter? The experience of urban nature's diversity: case study and cultural concept. Ecosystem Services 12:200-208

von Döhren P, Haase D (2015) Ecosystem disservices research: a review of the state of the art with a focus on cities. Ecol Indic 52:490-497

Wallace KJ (2007) Classification of ecosystem services: problems and solutions. Biol Conserv 139:235-246

Waran A (2001) Carbon sequestration potential of trees in and around Pune City. (MSc), University of Pune, Pune

Watson RT, Noble IR, Bolin B, Ravindranath NH, Verardo DJ, Dokken DJ (2000) Carbon pools that could be considered and how they are impacted by ARD activities. Land use, land-use change and forestry: A special report by the Intergovernmental Panel on Climate Change. http://www.ipcc.ch/ipccreports/sres/land_use/index. php?idp=131. Accessed 12 June 2015

Wise S, Braden J, Ghalayini D, Grant J, Kloss C, MacMullan E, Morse S, Montalto F, Nees D, Nowak D, Peck S, Shaikh S, Yu C (2010) Integrating valuation methods to recognize green infrastructure's multiple benefits. Low Impact Development 2010, Redefining Water in the City, San Francisco

Woods-Ballard B, Kellagher R, Martin P, Jefferies C, Bray R, Shaffer P (2007) C697 The SUDS manual. Construction Industry Research and Information Association, London

Woods-Ballard B, Wilson S, Udale-Clarke H, Illman S, Scott T, Ashley R, Kellagher R (2015) C753 The SuDS manual. Construction Industry Research and Information Association, London

Young CH, Jarvis PJ (2001) Assessing the structural heterogeneity of urban areas: an example from the black country (UK). Urban. Ecosystems 5:49-69 